\title{
PENGELOLAAN ARSIP \\ DENGAN APLIKASI DATA DEBITUR PINJAMAN \\ PADA PT BANK MANDIRI (Persero) Tbk. CABANG KCP GRAHA BINTARO
}

\author{
Siti Zubaidah ${ }^{1}$ \\ Dosen Prodi D-III Sekretari Universitas Pamulang \\ sitizubaidah_49@ymail.com \\ Syamsul Agus Sanjaya ${ }^{2}$ \\ Mahasiswa Prodi D-III Sekretari Universitas Pamulang \\ ajaysanjaya58@gmail.com
}

\begin{abstract}
ABSTRAK-File adalah kumpulan dokumen yang disimpan secara sistematis karena digunakan sehingga dapat dengan cepat ditemukan kembali apabila dibutuhkan. File mempunyai peranan penting di kantor. Jika catatan yang mereka miliki tidak dikelola dengan baik, maka sulit untuk menemukan informasi yang tersimpan, yang dapat menghambat kegiatan selanjutnya dalam proses kerja. Oleh karena itu, catatan harus dikelola dengan sistem manajemen file yang baik dan benar.

Tujuan dari penelitian ini adalah untuk mengetahui Standar Operational Prosedur (SOP) dalam pengelolaan arsip , untuk mengetahui tempat dalam penyimpanan arsip pada, dan untuk mengetahui aplikasi yang digunakan dalam pengelolaan arsip pada PT. Bank Mandiri (persero) Cabang Kcp Graha Bintaro.

Teknik pengumpulan data yang digunakan adalah data observasi dan melakukan observasi serta metode kerja langsung di kantor PT Bank Mandiri (Persero), KCP Graha Bintaro. Kesimpulan yang dapat ditarik dari pengamatan ini adalah bahwa masih banyak karyawan yang tidak mengerti bagaimana cara mengelola arsip dengan menggunakan aplikasi dan sesuai dengan standar Operasional prosedur (SOP) yang terdapat di Bank Mandiri (persero) Cabang KCP Graha Bintaro.
\end{abstract}

Kata-kata Kunci: Pengelolaan Arsip, Aplikasi Data

\begin{abstract}
The archive is a collection of scripts that are stored systematically because they have uses so that whenever needed they can be quickly recovered. Archives have an important role in an office, if the records that are owned are not well managed, it can be difficult to find information that has been stored and ultimately can hamper the next stage of the work process. Therefore, records should be managed using a good and correct archive management system. The purpose of this study is to determine the Standard Operational Procedure (SOP) in managing archives, to find out the place in the archive storage, and to find out the applications used in managing records at PT. Bank Mandiri (Persero) Kcp Graha Bintaro Branch. Data collection techniques used are by observation, and make observations and work practices directly at the office of PT Bank Mandiri (Persero) Branch KCP Graha Bintaro. The conclusion that can be drawn from this observation is that there are still many employees who do not understand how to manage records using the application and in accordance with standard operating procedures (SOP) found at Bank Mandiri (Persero) KCP Graha Bintaro Branch
\end{abstract}

Keywords: Archive Management, Data Applications

\section{PENDAHULUAN}

\section{Latar Belakang Masalah}

File adalah setiap catatan (catatan dokumen) yang ditulis, dicetak atau diketik dalam bentuk huruf, angka atau gambar yang memiliki arti atau tujuan tertentu, seperti bahan komunikasi dan informasi yang direkam pada kertas, film, media komputer, dll, karena 
pentingnya fungsi file ini, maka file dapat digunakan sebagai pertimbangan penting dalam menentukan pedoman masa depan untuk suatu organisasi (Sri Endang, 2011: 8).

Menurut kamus administrasi, kearsipan adalah bentuk pekerjaan administrasi dalam bentuk penyusunan dokumen yang sistematis, sehingga lebih banyak dokumen dapat ditemukan dengan cepat, jika diperlukan (Agus Sugiarto dan Teguh Wahyono, 2010: 2).

Arsip memainkan peran penting dalam perjalanan organisasi, karena pentingnya file untuk penggunaan data debitur, kami memerlukan prosedur registrasi yang baik sehingga manajemen arsip dilakukan dengan lancar dan akurat. Dalam sebuah organisasi di bidang arsip, ini adalah bagian sekretariat atau administrasi, oleh karena itu, untuk dapat menyimpan arsip, keterampilan khusus di bidang arsip harus tersedia sehingga tujuan yang dicapai dapat dicapai secara memadai.

Perusahaan juga selalu membutuhkan bantuan data dan informasi untuk melakukan pekerjaan dan membuat administrasi menjadi efektif untuk mencapai tujuan. Salah satu cara perusahaan mengatasi perkembangan teknologi adalah memiliki sistem informasi yang sangat bagus, cepat, dan lengkap. Nilai informasi ditentukan oleh lima karakteristik, yaitu: ketepatan, ketepatan waktu, integritas, efisien,dan efektif, untuk itu dibutuhkan fasilitasi kerja yang baik dari perusahaan. Untuk mencapai ini, arsip sangat penting dalam suatu perusahaan, yang dikelola baik secara manual maupun digital.

Dalam sebuah perusahaan, arsip perlu untuk memberikan layanan kepada pihak lain dan untuk kebutuhan informasi internal perusahaan. Arsip memiliki dampak besar pada semua kegiatan yang terkait dengan manajemen di semua bidang perusahaan. Arsip juga merupakan pusat memori perusahaan, dan penggunaan data kredit pelanggan dapat mengungkapkan berbagai jenis informasi yang sudah dimiliki perusahaan, untuk menentukan tujuan yang ingin dicapai menggunakan potensi maksimum yang tersedia. Informasi yang diperoleh melalui penggunaan data debitur juga dapat menghindari kesalahpahaman antara debitur internal, penggunaan data ganda debitur dan membantu mencapai efisiensi kerja.

Sistem manajemen arsip mencakup beberapa aktivitas untuk mengklasifikasikan, memberi kode, menyimpan, dan mengelola data dengan benar untuk menghapus dan memusnahkan data yang tidak lagi digunakan. Sistem adalah seperangkat komponen reguler yang terkait dengan rencana yang dibuat untuk mencapai tujuan. Sedangkan manajemen adalah proses yang membantu merumuskan kebijakan dan tujuan organisasi, atau proses yang memberikan gambaran umum tentang masalah yang terkait dengan implementasi 
dan pencapaian kebijakan (Ibnu Syamsi, 2011: 8).

Jika arsip perusahaan tidak dikelola dengan baik, itu dapat menyebabkan masalah dengan lokasi aplikasi dari data yang disimpan pelanggan dan mungkin mengganggu kegiatan selanjutnya dari proses kerja. Dalam implementasinya, masih banyak file yang disimpan sehingga banyak data yang menumpuk dalam lemari arsip, sehingga arsip sulit untuk ditemukan kembali. Akibatnya, pemeliharaan informasi penting dalam data akan hilang, sehingga penyimpanan file yang baik dan teratur diperlukan agar data yang disimpan dapat dengan cepat ditemukan kembali.

Kendala lain dalam menumpuknya file dengan permintaan data peminjam dari Graha Bintaro cabang PT Bank Mandiri (Persero) adalah bahwa file tersebut tidak dihapuskan. Formulir permintaan data debitur tumbuh hari demi hari, tetapi tidak ditata dengan baik. Kurangnya pengubahan ukuran file ini berarti bahwa volume data di luar kendali dan efisiensi manajemen data terpengaruh.

Hal ini yang menarik perhatian penulis untuk melakukan penelitian tentang "Pengelolaan Arsip dengan Aplikasi Data Debitur Pinjaman Pada PT Bank Mandiri (Persero) Tbk Cabang KCP Graha Bintaro" sebagai topik bahasan. Mengingat peran arsip sangat penting, maka sebaiknya aplikasi data debitur pinjaman dikelola menggunakan sistem pengelolaan arsip yang baik dan benar.

\section{Perumusan Masalah}

Adapun perumusan masalah dari penelitian ini adalah :

1. Bagaimana Standar Operational Prosedur (SOP) dalam pengelolaan arsip pada PT Bank Mandiri (persero) Tbk, Cabang KCP Graha Bintaro?

2. Bagaimana tempat penyimpanan arsip yang terdapat pada PT Bank Mandiri (persero) Tbk, Cabang KCP Graha Bintaro? Dan

3. Bagaimana rincian aplikasi yang digunakan dalam penyimpanan arsip pada PT Bank Mandiri (persero) Tbk, Cabang KCP Graha Bintaro ?

\section{Tujuan Penelitian}

Tujuan dari penelitian ini adalah :

1. Untuk mengetahui Standar Operational Prosedur (SOP) dalam pengelolaan arsip pada PT. Bank Mandiri (persero) Cabang Kcp Graha Bintaro,

2. Untuk mengetahui tempat dalam penyimpanan arsip pada PT. Bank Mandiri (persero) Cabang Kcp Graha Bintaro.

3. Untuk mengetahui aplikasi yang digunakan dalam pengelolaan arsip pada PT. Bank Mandiri (persero) 
Cabang Kcp Graha Bintaro.

\section{Metode Penelitian}

Penulis membutuhkan data yang terkait dengan studi penulis tentang:

\section{Jenis Data}

a. Data Primer Yaitu sumber data yang dikumpulkan oleh penulis, yang dapat digunakan ceara langsung.

b. Data Sekunder Yaitu Data sekunder adalah sumber data yang digunakan oleh penulis melalui sarana perantara atau tidak langsung, dalam bentuk buku, situs web, dan arsip dalam file .

\section{Teknik Pengumpulan Data}

a. Data Primer Yaitu dengan cara observasi, melakukan pengamatan dan praktek kerja secara langsung di kantor PT Bank Mandiri (persero) Tbk Cabang KCP Graha Bintaro.

b. Data Sekunder Yaitu dengan cara membaca beberapa buku referensi mengenai Job Descriptiondi took buku dan perpustakaan Universitas Pamulang dengan materi Tugas Akhir ini. Penulis juga membaca beberapa buku dan dokumen mengenai organisasi dan $J o b$ Description di organisasi tersebut.

\section{LANDASAN TEORI}

\section{Pengertian Arsip}

Arsip berasal dari bahasa Yunani yaitu arche yang berarti pedang, Archea berarti dokumen / catatan. Archeon berarti tempat penyimpanan. Dalam etimologi file, diartikan sebagai dokumen atau catatan yang secara sistematis menyimpan.

Arsip memiliki makna yang berbeda dengan bahan pustaka yang terdapat di perpustakaan karena memiliki harus autentik dan terpercaya sebagai alat bukti yang sah, memiliki informasi utuh dan memiliki asal usul dan aturan asli.

Pengarsipan dalam bahasa Inggris berarti pengarsipan. File adalah objek, sedangkan file adalah aktivitas. Pengarsipan juga merupakan proses pengorganisasian catatan, yang dimulai dengan pembuatan, penerimaan, perekaman, dan penyimpanan. Proses pengarsipan menggunakan sistem khusus untuk membuat dan memelihara catatan, sehingga dapat ditemukan dengan cepat, akurat dan mudah untuk pemusnahan catatan sesuai dengan kriteria tertentu..

Pengertian kearsipan menurut para ahli adalah sebagai berikut :

1. Menurut Kamus Administrasi Perkantoran oleh Drs. The Liang Gie :

a. Penyimpanan dokumen (pengarsipan) adalah kegiatan pengarsipan dokumen dengan benar, sesuai dengan sistem, organisasi dan prosedur yang ditentukan, sehingga pertumbuhan dokumen dapat dikendalikan dan dapat dicari dengan cepat bila 
diperlukan. Lawan penyimpanan adalah penemuan kembali.

b. Sistem penyimpanan dokumen (sistem pengarsipan) terdiri dari serangkaian proses yang diatur sesuai dengan panduan untuk membuat dokumen, sehingga dokumen dapat ditemukan dengan tepat, jika perlu.

2. Menurut Kamus Administrasi

Pengertian kearsipan adalah semua rangkaian kegiatan penyelenggaraan kearsipan sejak saat dimulainya pengumpulan warkat sampai penyingkiran.

Memahami arsip, yaitu prosedur untuk mengelola penyimpanan dokumen sesuai dengan aturan dan prosedur yang berlaku, ada tiga elemen utama, yaitu : penyimpanan, penentuan posisi dan penemuan kembali.

\section{Fungsi Arsip}

Arsip sangat penting bagi pegawai, pimpinan, dan organisasi.Arsip Berfungsi sebagai sumber ingatan, sumber keterangan/informasi, bahan bukti sejarah/sumber sejarah, dan bahan pertanggungjawaban terhadap suatu kejadian atau peristiwa. Arsip berperan membantu ingatan seseorang untuk melakukan suatu tindakan, membantu pimpinan dalam pengambilan keputusan dan kebijakan, kelancaran proses administrasi, dan kelancaran proses penyelenggaraan organisasi

Sayuti (2013:156) juga mengelompokkan dokumen yang di simpan sebagai arsip, yaitu sebagai berikut.

1. Arsip aktif. Arsip yang masih dalam penyelesaian, atau arsip yang masih sering dikeluarkan atau digunakan untuk keperluan tertentu.

2. Arsip pasif, arsip yang jarang digunakan karena sudah selesai diproses hanya kadang-kadang saja masih diperlukan

Arsip abadi merupakan arsip penting dan berlaku untuk selama-lamanya atau seumur dengan organisasi atau badan sebagai pemiliknya.Contoh adalah Akte Pendiri Perusahaan.

\section{Peranan Arsip}

Peran arsip secara umum adalah untuk memastikan keamanan dan dapat dipertanggungjawabkan secara nasional dalam kaitannya dengan perencanaan, implementasi dan pengelolaan kehidupan nasional. Hal ini dapat disimpulkan bahwa peran file:

1. Alat utama ingatan organisasi

2. Bahan atau alat pembuktian (bukti otentik)

3. Bahan dasar perencanaan dan pengambilan keputusan 
4. Bahan informasi kegiatan ilmiah lainnya

\section{Macam-Macam Penyimpanan Arsip}

Penyimpanan arsip perlu dilakukan secara sistematis dalam suatu organisasi agar arsip dapat terjaga dan tertata rapi. Menurut Thomas Wiyasa dalam buku Manajemen Kearsipan Armida Silvia Asriel (2018), ada enam sistem penyimpanan arsip, yaitu :

1. Sistem Alfabet atau abjad

Dasar sistem alfabetik ini berdasarkan nama orang, perusahaan, atau organisasi yang dipergunakan sebagai judul.

\section{Sistem Nomor}

Merupakan sistem filling berdasarkan penyimpanan dan pengambilan berkas atau surat atas dasar kode nomor.

3. Sistem Pekerjaan atau Numerik, Mengidentifikasikan berdasarkan subjek pekerjaan dan Kartu indeks untuk pemberi nomor pekerjaan.

4. Sistem Geografik

Berdasarkan tata letak dalam ilmu bumi.

5. Sistem Subjek

Merupakan perihal untuk mengidentifikasi surat berdasarkan cakupan bidang usaha.

6. Sistem Kronologis

Berdasarkan urutan tanggal.

\section{Peralatan Kearsipan}

Jika kita berbicara tentang arsip, tentunya tak lepas dengan administrasi dan berhubungan dengan organisasi.Kegiatan menyimpan dokumen arsip menggunakan peralatan arsip.. Peralatan ini pada umumnya dibuat menggunakan bahanbahan yang tahan lama seperti, logam, kayu, alumunium, besi, plastik, maupun alat kuat lain sebagainya.

Fungsi peralatan arsip adalah sebagai berikut:

1. Sebagai sarana penyimpanan arsip

2. Alat bantu untuk mempercepat, meringankan, dan mempermudah pekerjaan dibidang kearsipan

3. Alat pelindung arsip dari bahaya kerusakan, sehingga arsip bertahan lama.

Macam-macam peralatan kearsipan yang digunakan untuk melakukan menyimpan dokumen.

1. Filling cabinet

2. Lemari Arsip

3. Rak Arsip

4. Map Arsip

5. Ordner

6. Guide

7. Stapler

8. Label

9. Perpurator

10. Bak sortir

11. Tickler file

12. Cardex

13. Numerator 
14. Rotary Filling (alat penyimpanan berputar)

\section{Aplikasi Data dalam Perbankan}

Memahami penggunaan data di sektor perbankan mencakup penggunaan komputer dan alat pendukung bank, yang meliputi: mencatat, menghitung, meringkas, mengklasifikasikan, dan melaporkan semua aktivitas sektor perbankan. Kegiatankegiatan ini dapat meliputi administrasi, akuntansi, administrasi, pemasaran atau bidang lain yang mendukung kegiatan perbankan.

Dengan bank yang ada di Indonesia, dapat dikatakan bahwa tidak ada sistem aplikasi perbankan yang dapat diklasifikasikan sebagai terintegrasi penuh. Dapat dikatakan bahwa sistem aplikasi data yang ada telah menerapkan hampir seluruh atau sebagian dari keseluruhan sistem pemrosesan aplikasi yang terkait dengan pengelolaan dana publik (sistem permintaan setoran).

Sistem aplikasi data perbankan yang lengkap dan terintegrasi meliputi: sistem informasi keuangan (sistem informasi keuangan) sistem pemrosesan transaksi (sistem pemrosesan aplikasi) sistem pemrosesan aplikasi, sistem keputusan manajemen (sistem pengambilan keputusan pembayaran) manajemen) dan sistem informasi pelanggan (sistem informasi pelanggan). Bank umumnya memiliki aspek seperti kapasitas dokumentasi atau penyimpanan data, fleksibilitas, sistem keamanan, kemudahan penggunaan, sistem pelaporan, aspek pemeliharaan dan pemeliharaan kode sumber.

Aplikasi data ini salah satu syarat awal pengajuan calon debitur untuk melakukan pinjaman pada suatu perbankan, tanpa adanya aplikasi data calon debitur tidak dapat melalukan transaksi dengan bank. Karena aplikasi ini berisikan data calon debitur seperti, jumlah pengajuan, tujuan pengajuan, jangka waktu, data pemohon, datasuami/istri, data usaha, data kerabat dekat yang tidak serumah, data keuangan calon debitur, dan tandatangan pihak calon debitur dan pihak bank yang menyetujui.

\section{Fungsi Aplikasi Data}

Fungsi aplikasi data seperti sebuah perpustakaan yaitu untuk menyimpan banyak buku - buku dari berbagai kategori, di mana satu buku menyimpan berbagai data, mulai judul buku, nama pengarang, ringkasan isi, penerbit, tahun penerbitan, dll. Demikian halnya dalam aplikasi data menyimpan informasi suatu obyek yang didalamnya terkandung serpihan - serpihan data. Adapun fungsi aplikasi adalah sebagai berikut :

1. Mengelompokkan data untuk mempermudah mengidentifikasi, 
aplikasi menyiapkan data yang sesuai dengan permintaan debitur terhadap suatu informasi dengan cepat dan akurat.

2. Menghindari data ganda dan inkonsistensi data.

3. Merupakan syarat utama dalam melakukan transaksi pada pihak bank.

4. Menjadi bahan pertimbangan pimpinan dalam memperoses pengajuan calon debitur pinjaman pada pihak bank.

5. Menjaga kualitas data dan informasi agar data tetap sama pada saat entry dan setelah entry, dan data tidak hilang atau resiko kerusakan selama penyimpanan.

\section{HASIL DAN PEMBAHASAN}

Menurut data yang dikumpulkan di lapangan, disesuaikan dengan rumusan masalah dan tujuan penulisan, dan juga sesuai dengan langkah-langkah dan metode pengumpulan data pada bab sebelumnya, penulis kemudian akan membahas standar operasional prosedur dalam pengelolaan arsip pada PT Bank Mandiri (persero) Tbk, Cabang KCP Graha Bintaro sebagai berikut:

\section{Prosedur Pengelolaan Arsip Di Unit}

\section{Kerja}

\section{Pemberkasan}

Pemberkasan dokumen adalah pengelolaan kegiatan, serta modalitas untuk membuat informasi yang diarsipkan, yang mempunyai persamaan kegiatan atau kesamaan masalah.
Tujuan dari pemberkasan adalah untuk menghasilkan informasi.

Prosedur pemberkasan arsip di unit kerja adalah sebagai berikut:

1. Pemberkasan arsip dilakukan terhadap dokumen yang dibuat dan diterima oleh pegawai yang ditetapkan berdasarkan klasifikasi masalah sebagaimana ditentukan dalam petunjuk teknis operasional jadwal retensi dokumen.

2. Arsip yang telah ditetapkan klasifikasi masalahnya tersebut selanjutnya ditata berdasarkan urutan:

a. Angka (Numerik), misalnya arsip pegawai ditata menurut urutan Nomor Induk Pegawai (NIP).

b. Abjad (Alfabetis), Misalnya arsip nasabah atau rekanan bank ditata menurut urutan abjad nama perusahan.

c. Kronologis waktu, misalnya arsip berupa bukti pembukuan ditata menurut urutan tanggal dan disimpan dalam bundle temple.

d. Wilayah (geografis), misalnya arsip supervise cabang ditata menurut urutan wilayah kerja.

3. Dokumen yang telah diberkas disimpen dalam folder, map, odner atau bundle temple dan diberi kode masalah dan judul berkas secara singkat dan jelas pada tempat yang langsung mudah dapat dilihat. 
4. Dokumen bukti pembukuan atau bukti asli transaksi harian diberkas secara khusus menggunakan bundel tempel atau dijilid. Punggung bundel tempel atau penjilidan diberi keterangan nomor uruut bundel pertahun, tanggal transaksi dan nomor rak/lemari penyimpanan di unit kerja.

5. Dokumen yang disimpan dalam folder, map atau ordner dicatat dalam lembar Daftar Isi Berkas (DIB) untuk memastikan dan memudahkan pengecekan kelengkapan dokumen.

6. Dalam hal terdapat dokumen atau lampiran yang bentuknya tidak dapat disimpan dalam folder, map, atau ordner berkas yang bersangkutan, misalnya buku, peta, bagan, tape, diskette dan lainlain dapat disimpan dalam sarana penyimpanan tersendiri, namun dalam DIB tersebut tetap mencantumkan jenis dokumen dan keterangan lokasi simpannya.

7. Folder, map atau ordner yang telah diberi kode masalah dan judul berkas tersebut selanjutnya ditata secara berderet atau lateral dalam lemari arsip, filling cabinet, cradenza mobile file atau sarana penyimpanan lainnya.

\section{Penyimpanan Fisik}

Tujuan penyimpanan fisik dokumen atau arsip adalah agar dokumen atau arsip tetap dalam kondisi aman, terjaga dan terpelihara informasi dan keamanan fisiknya, serta mudah ditemukan kembali apabila diperlukan. Penyimpanan fisik dilakukan terhadap dokumen atau arsip yang sudah didaftar dalam Daftar Berkas Unit Kerja. Prosedur penyimpanan fisik dokumen atau arsip di unit kerja antara lain sebagai berikut:

1. Penyimpanan fisik dokumen atau arsip dilakukan di tempat yang mudah diawasi.

2. Ruangan dan sarana penyimpanan fisik dokumen atau arsip dalam keadaan terkunci apabila tidak digunakan.

3. Penyimpanan fisik dokumen atau arsip dilakukan dengan tetap menjamin arsip dapat diakses secara cepat, tepat, aman dan mudah.

4. Dokumen vital antara lain dokumen agunan, dokumen asli yang dititipkan oleh pihak ketiga atau rekanan atau nasabah, dokumen berupa bukti kepemilikan asset atau perizinan usaha bank wajib disimpan tersendiri dalam lemari besi tahan api atau sarana penyimpanan lain yang aman dibawah pengawasan pegawai pimpinan yang berwenang. Setiap dokumen vital yang disimpan tersebut dibuat Daftar Isi Dokumen Vital dan dibuat penggandaannya yang disimpan secara terpisah (dipersal) sebagai back up.

5. Setiap arsip wajib disimpan selama jangka waktu penyimpanan sesuai 
Petunjuk Teknis Operasional Jadwal Retensi Dokumen.

6. Penemuan kembali dokumen dapat dipedoman pada klasifikasi masalah, judul berkas dan DIB.

7. Setiap peminjaman dokumen di unit kerja wajib dicatat dan dibuat bukti tanda terima peminjamannya. Demikian pula saat menerima kembali dokumen yang dipinjam dibuatkan bukti tanda terima pengembaliannya.

\section{Penyiangan}

Penyiangan dokumen arsip adalah kegiatan memilah, mengeluarkan, dan menyisihkan dokumen atau arsip untuk dilakukan pemusnahan atau pemindahan penyimpanan ke Pusat Arsip. Setiap pegawai pengelola dokumen atau arsip di unit kerja wajib melakukan kegiatan penyiangan secara berkala untuk menentukan hal-hal sebagai berikut:

1. Non dokumen atau arsip seperti amplop, map, brosur, majalah, surat kabar, duplikasi atau surplus copies yang dapat segera dimusnahkan setelah disetujui oleh pimpinan unit kerja.

2. Dokumen atau arsip yang telah berakhir jadwal retensinya sampai dengan 2 tahun dan tidak mempunyai nilai guna lagi dikelompokkan dan diusulkan pemusnahanya kepada pimpinan unit kerja.
3. Arsip yang mempunyai jadwal retensi dokumen di atas 2 tahun dapat dipindahkan penyimpanannya di Pusat Arsip.

\section{Pemusnahan}

Pemusnahan adalah kegiatan menghancurkan secara total arsip yang telah berakhir fungsinya dan yang tidak lagi memiliki nilai guna bagi unit kerja. Pemusnahan arsip di unit kerja dapat dilakukan terhadap arsip antara lain:

1. Telah melewati ketentuan wajib

2. simpannya sesuai Petunjuk Teknis Operasional jadwal retensi dokumen.

3. Tidak memiliki nilai guna.

4. Tidak ada peraturan perundangundangan yang melarang.

5. Tidak berkaitan dengan penyelesaian proses suatu perkara.

\section{Prosedur Pemeliharaan Dan}

\section{Pengamanan Arsip}

\section{Pemeliharaan arsip}

Pemeliharaan arsip adalah kegiatan untuk merawat, melindungi dan memperbaiki agar arsip tidak rusak dan dapat bertahan lama sesuai dengan ketentuan retensi atau jangka waktu simpannya. Pada dasarnya kerusakan arsip dapat disebabkan oleh faktor internal (unsur-unsur kertas, tinta, pasta atau lem) dan faktor eksternal, yakni 
biologis (jamur dan serangga, rayap, ngengat, kutu buku yang suka makan kertas, serta kecoa dan rikus yang suka bersarang di celah-celah atau di belakang kotak arsip, rak atau lemari memakan kertas atau bersarang), fisik (cahaya, panas, dan air), kimiawi (pencemaran udara, gas asidik, debu), bencana (kebakaran, banjir, gempa) dan manusia baik disengaja maupun tidak. Kegiatan pemeliharaan arsip dapat dilakukan dengan prosedur pemeliharaan yang bersifat pencegahan (preventif) dan bersifat perbaikan (restorasi)

1. Pemeliharaan arsip yang bersifat pencegahan. Untuk mencegah agar arsip yang disimpan di Pusat Arsip selalu terjaga dan terpelihara kondisi fisik maupun informasinya, perlu diperhatikan dan dilakukan prosedur pemeliharaan sebagai berikut:

a. Suhu atau temperature dan tingkat kelembaban udara (relative humadity) dalam ruang penyimpanan arsip akan sangat berpengaruh untuk arsip yang mempunyai retensi atau jangka waktu simpan yang lama. Ruang penyimpanan arsip yang kondisinya baik dengan suhu tidak melebih 29 derajat celcius dan kelembaban udara tidak lebih dari $65 \%$.

b. Melengkapi ruang penyimpanan di Pusat Arsip dengan alat pengukur suhu dan tingkat kelembaban udara (thermohygrometer). c. Mencegah agar arsip tidak terkena langsung sinar matahari atau pencahayaan langsung.

d. Ruang penyimpanan arsip diberi ventilasi secukupnya agar ada sirkulasi udara. Apabila ruang tidak dilengkapi $\mathrm{AC}$ harus dilengkapi dengan kipas angina.

e. Membersihkan ruangan, rak dan kotak arsip dari debu secara rutin.

f. Menaburkan kapur barus atau kampher pad arak arsip secara berkala.

g. Membersihkan kotak arsip dengan menggunakan vacuum cleaner.

h. Apabila terdapat arsip atau kotak arsip yang rusak, basah atau indikasi diserang rayap segera dipisahkan dari ruangan.

i. penyimpanan untuk dilakukan perawatan. Hai ini dimaksudkan agar kerusakan arsip tidak dapat menyebar.

j. Mengecek kondisi arsip yang baru diterima dari unit kerja, untuk memastikan tidak terdapat ancaman bahaya rayap.

k. Melakukan pest control dan termite control atau fumigasi secara berkala.

1. Dilarang memegang arsip dengan tangan yang kotor atau basah.

m. Melarang pegawai merokok, membawa makanan dan minuman ke dalam ruang penyimpanan arsip. Ruang penyimpanan arsip juga dilarang ditempati tanaman hidup atau bahan lain yang dapat busuk dan mengundang serangga. 
n. Apabila hujan periksalah ruang penyimpanan arsip untuk mengetahui kemungkinan adanya talang, saluran air dan atap gedung yang bocor. Apabila terjadi kebocoran harus segera diperbaiki.

o. Melaksanakan pengawasan terhadap ruang penyimpanan, rak dan arsip secara berkala untuk memastikan kondisinya selalu terpelihara.

Tempat penyimpanan arsip pada PT Bank Mandiri (persero) Tbk Cabang KCP Graha Bintaro.Terdapat banyak tempat penyimpanan arsip, tetapi masih banyak karyawan yang belum mengetahui fungsi tempat penyimpanan arsip. Dibawah ini adalah nama peralatan yang digunakan untuk menyimpan arsip PT Bank Mandiri (persero) Tbk Cabang KCP Graha Bintaro yaitu :

1. Map aplikasi data debitur pinjaman

2. Kastuken

3. Ordner kecil

4. Ordner besar

5. Rak arsip

6. Filling cabinet

\section{Kardus Atau Box Arsip}

Setelah merumuskan tentang penyimpanan arsip pada PT Bank Mandiri (persero) Tbk Cabang KCP Graha Bintaro.Penulis berharap agar karyawan tidak lagi menyalahgunakan tempat penyimpanan arsip, agar menempatkan arsip sesuai dengan ketentuan yang telah di tetapkan oleh managemen.

Tahapan-tahapan pengelolaan arsip dengan aplikasi data debitur pinjamanmenggunakan sistem softcopy pada PT Bank Mandiri (persero) Tbk Cabang KCP Graha Bintaro, adalah sebagai berikut :

\section{Mengumpulkan Data}

Calon debitur adalah nasabah bank yang ingin mengajukkan pinjaman pada perbankan, dalam hal ini calon debitur mengumpulkan data-data pribadinya untuk melakukan persyaratan pinjaman.

\section{Persetujuan}

Setelah data debitur sudah terkumpul, maka Marketing Sales memberikan data tersebut kepada Kelapa Cabang agar disetujui.

\section{Scoring}

Setelah data disetujui oleh Kepala Cabang, data akan diinput sistem dengan Analis. Dan melakukan konfirmasi kembali dengan calon debitur untuk memastikan data-data tersebut benar miliknya dan tidak diduplikasi oleh pihak manapun.

\section{Pendataan Arsip}

Setelah data discoring dan dikonfirmasi ke calon debitur, maka tahapan selanjutnya adalah pendataan atau membukukan arsip.Tujuan pendataan arsip memudahkan 
dalam penyusunan untuk menghemat ruang atau tempat, menyatukan informasi arsip dan mudah ditemukan apabila diperlukan.

\section{Scanning}

Sebelum data di arsipkan, data tersebut di scan terlebih dahulu apabila terjadi hal yang tidak di inginkan seperti data fisik mengalami kerusakan atau kehilangan, perusahaan mempunyai data duplikat pada komputer.

\section{Pengarsipan Data}

Setelah data di scan, tahapan selanjutnya adalah mengarsipkan arsip berdasarkan tahun pengajuan dan nomor perjanjian kredit.

\section{PENUTUP}

\section{Kesimpulan}

Berdasarkan hasil diskusi pada bab sebelumnya, penulis dapat menarik kesimpulan sebagai berikut : Standar Operasional Prosedur (SOP) prosedur pengelolaan arsip di unit kerja meliputi : pemberkasan, penyimpanan fisik, penyiangan, pemusnahan dan pemindahan arsip. Tempat penyimpanan arsip sudah tersedia, tetapi masih banyak karyawan yang belum mengetahui fungsi tempat penyimpanan arsip. Sehingga sering disalahgunakan sebagai tempat penyimpanan arsip yang mengakibatkan penumpukkan arsip menjadi berantakan, rusak bahkan hilang. Berdasarkan suatu sistem yang memenuhi persyaratan,tahapan secara rinci pengelolaan arsip dengan aplikasi data debitur pinjaman meliputi : mengumpulkan data, persetujuan, scoring, pendataan arsip, scanning, pengarsipan data.

Dari uraian di atas, penulis dapat memberikan saran kepada divisi pengelolaan arsip pada PT Bank Mandiri (Persero) Tbk KCP Graha Bintaro adalah sebagai berikut : Sebaiknya kantor pusat pada PT Bank Mandiri (persero) Tbk memberikan training atau pelatihan untuk staf dan karyawan di Cabang KCP Graha Bintaro, dan mengadakan workshop untuk karyawan, agar mereka lebih memahami Standar Operasional Prosedur (SOP) yang ada dan bias mengaplikasikan melalui pekerjaannya. Untuk mengurangi hambatan dalam pengelolaan arsip, karyawan harus mengetahui macam-macam tempat penyimpanan arsip yang adapada PT Bank Mandiri (persero) Tbk Cabang KCP Graha Bintaro, agar tidak lagi menyalahgunakan tempat penyimpanan arsip, dan agar tidak mengalami kesalahan pada tahapan pengelolaan arsip, karyawan harus mempelajari dengan baik proses pengarsipan dalam pengaplikasian secara softcopy, karena untuk mempertanggungjawabkan keberhasilan dan kegagalan pelaksanaan kegiatan organisasi dalampengarsipan untuk 
mencapai sasaran dan tujuan yang telah ditetapkan.

\section{DAFTAR PUSTAKA}

\section{Sumber Buku}

Endang, Sri (2011), "Pengertian Arsip" Jilid 8, Bandung

Gie, The Liang, (2012) "Kearsipan" Menurut Administrasi Perkantoran, Jakarta

Sayuti (2013:156), "Fungsi Arsip", Managemen Kearsipan, Penerbit Armida Silvia Asriel, Padang, 2018

Sugiarto, Agus, dan Teguh Wahyono. (2010:12), "Kearsipan", dalam Kamus Administrasi

Syamsi, Ibnu. (2011:8), "Sistem Pengelolaan", Managemen Kearsipan, Penerbit Sambas Ali Muhidin, M. Si, dan Drs. Henri Winata, M. Si, Lingkar Selatan, 2016

Terry (2016), "Pengertian Kearsipan", Edisi 1, Managemen Kearsipan, Penerbit Sambas Ali Muhidin, M. Si, dan Drs. Henri Winata, M. Si, Lingkar Selatan

Wiyasa Thomas (2018), "Macam-macam Penyimpanan Arsip", Buku Managemen Kearsipan, Penerbit Armida Silvia Asriel, Padang

Yanuar (2016), “Pengertian Arsip”, Edisi 3, Buku Ekonomi Makro, Jakarta

\section{Zakky (2018), "Pengertian Kearsipan secara} Umum", Jakarta Monuments. In Encyclopedia of local history. (pp. 363364) Lanham, MD: AltaMira Press.

\section{$\underline{\text { Surat Kabar Cetak }}$}

Rosenberg, G. (1997, March 31). Electronic discovery proves an effective legal weapon. The New York Times, p. D5.

\section{Surat Kabar Online}

Rosenberg, G. (1997, March 31). Electronic discovery proves an effective legal weapon. The New York Times. Diakses dari http://www.nytimes.com

\section{Majalah Cetak}

Tumulty, K. (2006, April). Should they stay or should they go? Time, 167(15), 3-40.

\section{$\underline{\text { Majalah Online }}$}

Tumulty, K. (2006, April). Should they stay or should they go? Time, 167(15). Diakses dari http://content.time.com/time/magazine /article/0,9171,1179361,00.html 